\title{
NAGA ORNAMENTS AND THE INDIAN OCEAN
}

\author{
Alok Kumar Kanungo \\ Deccan College Post-Graduate \& Research Institute, Pune - 411006, India
}

\begin{abstract}
Naga communities in northeastern India and Myanmar have lived in isolation from the sea for centuries, but in their traditional ornaments they wear stone beads from the Gulf of Kutch and shells from the Bay of Bengal. Large-scale use of such cultural materials from the sea raises more questions than answers. There are many groups and sub-groups among the Nagas and each group/sub-group has its own unique traditional attire and ornaments, each element of which is closely bound up with the customs of that group. This paper attempts to explore the ornaments and costume accessories of the Nagas with special emphasis on the material originating from the Indian ocean. The paper is confined mostly to the ethnographic record from the $19^{\text {th }}$ and $20^{\text {th }}$ centuries.
\end{abstract}

\section{INTRODUCTION}

The habitat of the Nagas lies between the Brahmaputra plains of India and the hill ranges to the west of the Chindwin valley in upper Myanmar. The majority of the Nagas live on the Indian side and are spread throughout the states of Nagaland, Arunachal Pradesh and Manipur; the majority of them in Nagaland. There are sixteen major groups of Nagas, viz. the Angami, Ao, Chakhesang, Chang, Chirr, Khiamnungan, Konyak, Lotha, Makware, Phom, Rengma, Sangtam, Sema, Tikhir, Yimchunger and Zeliang. Of these, the first nine groups inhabit Nagaland (Fig. 1). All speak languages belonging to the TibetoBurman language family.

The origins of the Nagas are veiled in obscurity. One theory postulates that they migrated from China to their present home following the overland routes extensively used by Chinese traders and embassies between China and India (Ganguli 1984: 6).

\section{EARLY TIMES}

The Nagas were never subjugated by any external political agency, except for occasional encounters with the Ahom kings, until British annexation in 1826. The first historical record of them is that of Hiuen Ts'ang, who reached Kamarupa (Guwahati) in AD 638 at the invitation of the Assamese ruler Bhaskara-Varman Kumara. Hiuen Ts'ang's report refers to a profuse use of glass beads by the people of Assam, at a time when the major trade route from China to India led through Assam. There is also a reference to Assam in the biography of King Harsa of north India, a friend and ally of Bhaskar-Varman, in the form of the seventh century epic poem Harsa-Carita. Bagchi (1944) and Needham (1954) mention an earlier Chinese source, that of Chang K'ien (Western Han, 138 $\mathrm{BC}$ ), that refers to the existence of a trade route between Szechuan and India via Yunnan and Myanmar or Assam.

After the thirteenth century AD there exists reliable information about Assam and the Nagas in the records relating to Assam and Buranji, the chronicle of the Ahoms, who invaded Assam in AD 1228-30. The Ahoms (Ahams) were Shans from upper Myanmar who ruled Assam for nearly six hundred years, up to the annexation of the province to British India in 1826. There was also a short interval of Myanmar control between 1819 and 1824. The Buranji chronicle, written in the courts of the Ahom rulers, provides a wealth of information about the contacts between the Ahoms and the Nagas and other inhabitants of the neighbouring hills.

The first Europeans to visit the region of the formidable Nagas were the British military officers Major Francis Jenkins, Captain Pemberton and Lt. Gordon. They were exploring a route for communication across the mountains between Assam and Manipur in January 1832. After this, there followed the slow annexation of Naga territory into the British fold.

The first real interaction of the Nagas with outsiders took place during the First World War, when 2000 of them were recruited for service in France. The Nagas, however, came into major contact with the plains people only during the Japanese invasion in 1939-45. This event transformed their traditional way of living. The trading systems before 1939-45 are now a page in India's history, to be remembered and recorded but never to be observed again. For instance, 82-year old Aung Khestso Sale and his seventy-eight year old wife Ngunyu of Kigwema village, $12 \mathrm{~km}$ south of Kohima, told me in 1998 that they used to get beads and other ornaments from Myanmar and China before the war. There had been instances when Sale himself had walked into Myanmar to buy beads. But after the Japanese invasion this communication came to a halt and now they get their stone and glass beads, conch shells (Turbinella pyrum) and cowrie shells (Moneta moneta) from Khambat (Gujarat), south India, and Bengal. As far as tubular shell beads are concerned, the Nagas today use the left-over columellas of the species Turbinella pyrum from the shell bangle industry of Bengal. They grind them 


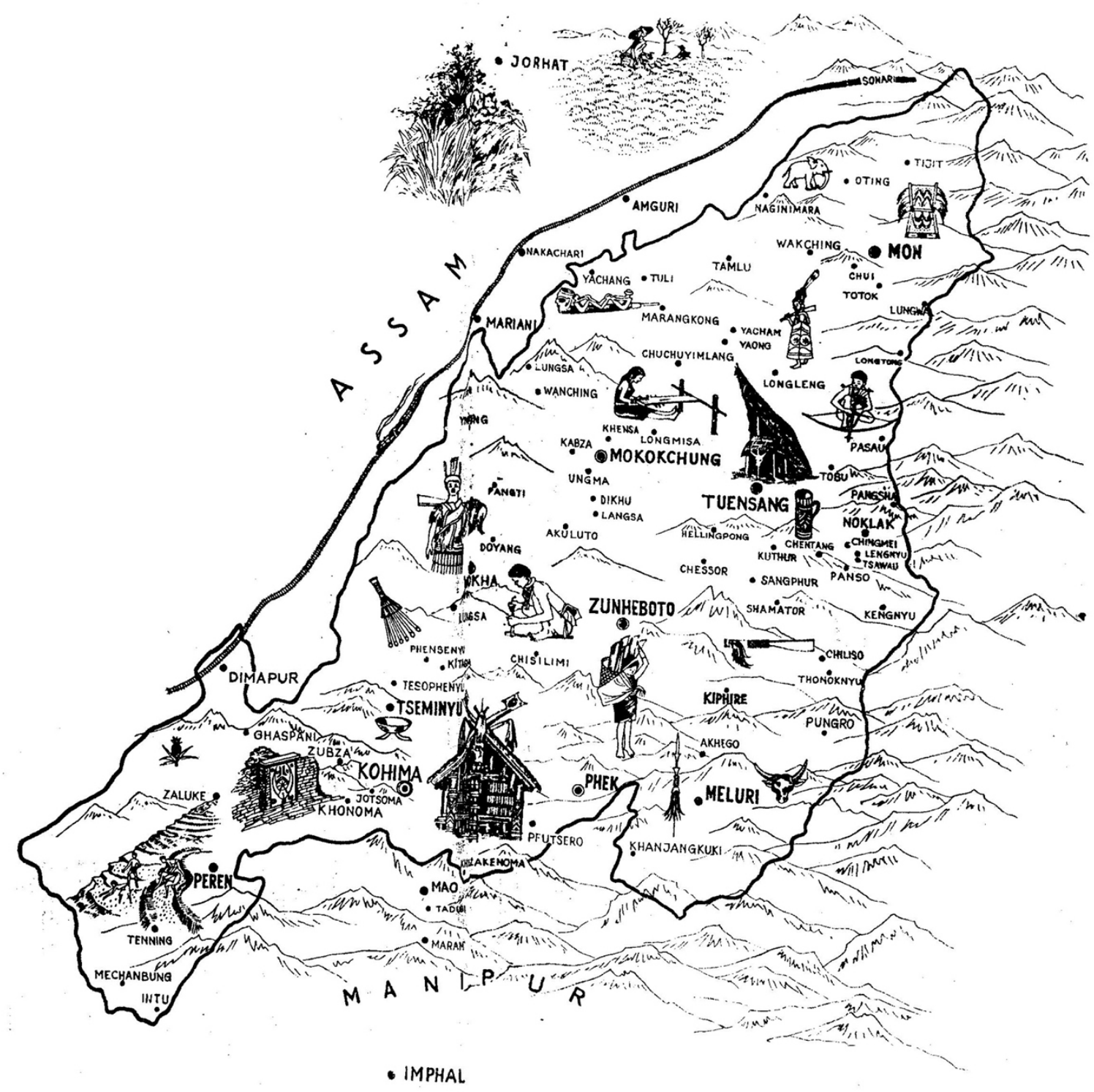

Fig. 1. Sketch map of Nagaland and its inhabitants.

into shape and perforate them with a bow-drill. Nowadays, Aung Khestso Sale does this for his family and friends, but generally not for business (Fig. 2). The Angamis of Khonoma and nearby villages have become masters of this craft.

\section{THE ORNAMENTS OF THE NAGAS}

Ornaments are very important to the Nagas, because besides fulfilling the decorative needs of the people, they serve visually to distinguish the warrior and commoner classes. Most of the ornaments are acquired in accordance with strict traditions.

Ornaments of marine origin like conch shells and cowries, Indo-Pacific glass beads traded by sea from the southeast Indian coast, and carnelian beads from western India, have been traditionally used by Nagas. R.G. Woodthorpe (1882a) mentioned that Naga ornaments consisted chiefly of a large number of necklaces composed of beads of all sorts and sizes, from large pieces of shell (three to five in a necklace) to the smallest glass beads.

Amongst the Naga in general, necklaces of long hexagonal carnelian and coloured glass beads, and beads of a peculiar dull yellow stone, decorate their necks. On the nape of the neck is often worn a large white conch shell (Turbinella pyrum), shaped so as to lie flat and suspended on a thick collar of dark blue cotton thread (Fig. 3). There are instance of a number of complete conch shells being tied to women's skirts (Fig. 4). The use of cowries is so common and prestigious that even the holder of a machete (called dao in Nagamese and by other names in Naga dialects), which a Naga carries all the time, is attached to a belt that is often profusely decorated with them (Fig. 5).

Individual Naga ethnic groups are distinctively marked by their attire and ornaments. J. Butler (1875:325) 


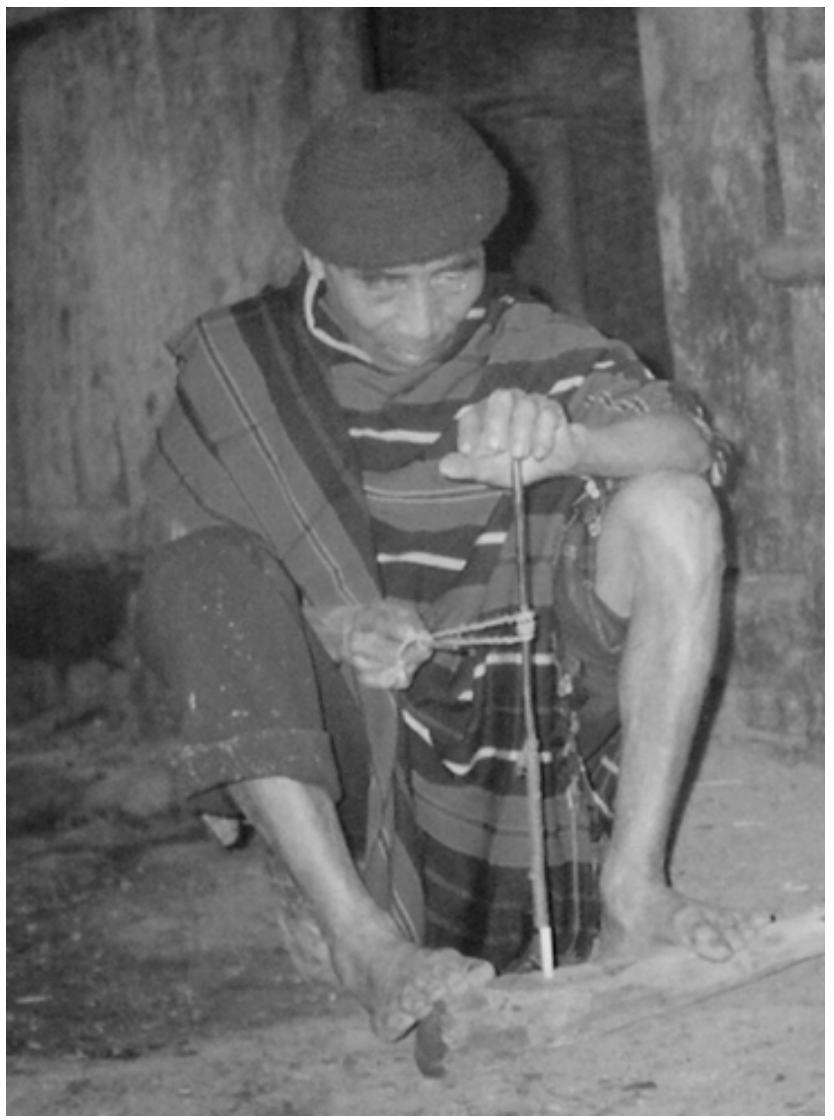

Fig. 2. Aung Khestso Sale displaying the shell drilling technique

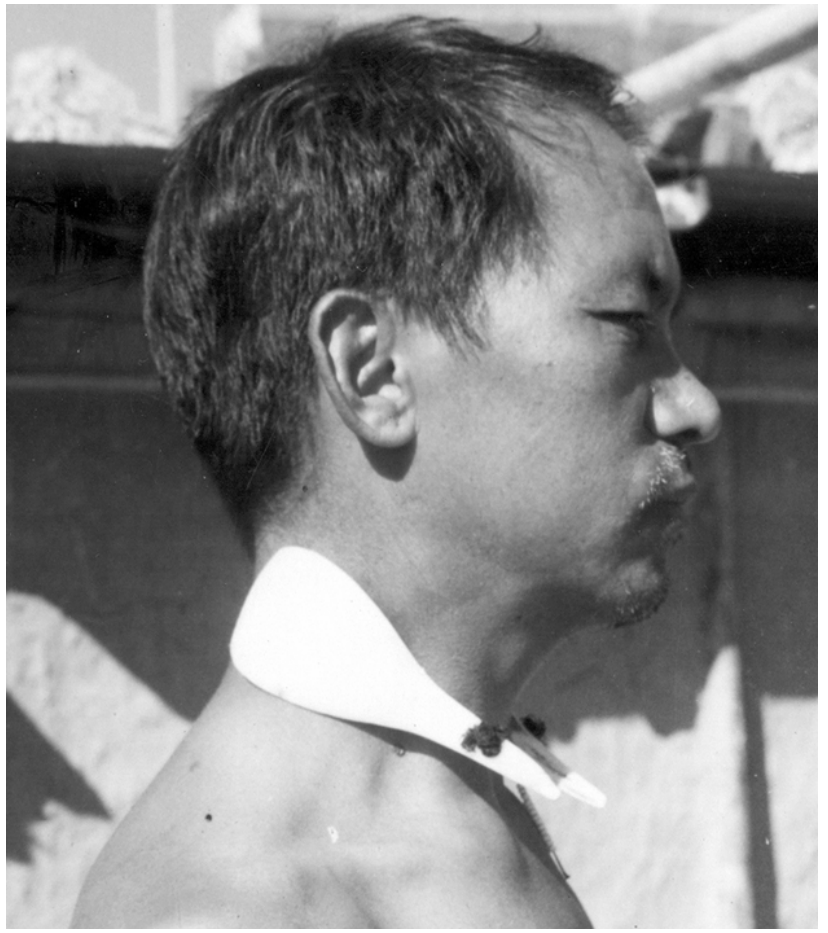

Fig. 3. A conch worn in the nape of the neck.

pointed out that "every Naga group uses a peculiar pattern of cloth, and thus any individual can at once be easily identified by his tartan.” The following sections describe

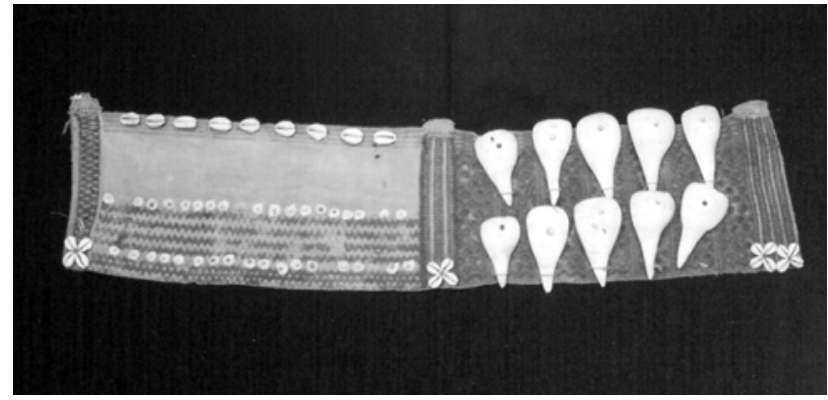

Fig. 4. A Naga cloth decorated with conches, cowries and disc beads.

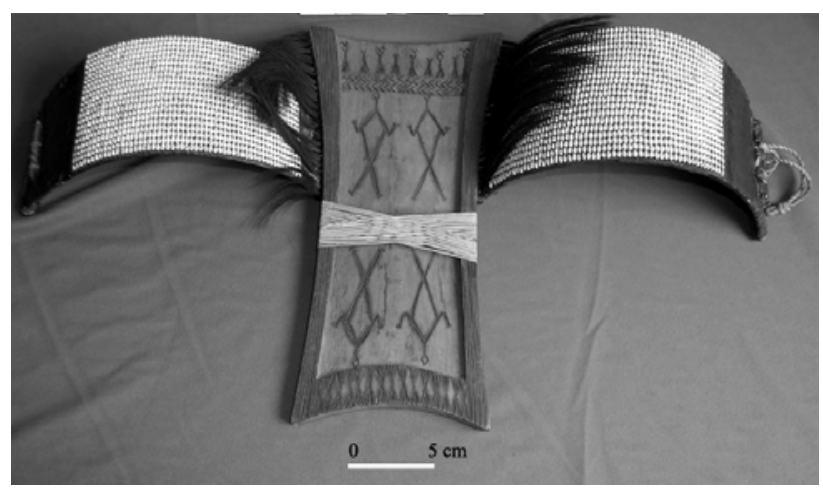

Fig. 5. A Naga dao case attached to a belt decorated with cowries.

the ornaments of four major Naga groups in Nagaland the Sema, Ao, Konyak and Angami.

\section{The Sema}

The Sema Nagas wear two kinds of necklets. One (Fig. 6) consists of single or multiple pairs of boar tusks bound with cane and fastened together under a large conch shell button with a red carnelian bead in the centre (aminihu). Traditionally, this could only be worn by those who had taken a head or killed a leopard. The aminihu is also worn by the Aos, Changs, Lhotas, Tangkhuls and Sangtams, and very rarely by the Angamis. The other type of necklace (ashoghila), worn universally by Sema men, has three or four strings of sliced white conch shell kept apart by bone spacers. In order to keep the necklace flat around the neck, at one end of the string a carnelian bead is placed over a conch shell square button with rounded corners, and it is inserted into a loop at the other end of the string. The wearing of carnelian bead necklaces is common among both Sema and Angami men. Those used by the Angamis are generally faceted and mostly hexagonal, whereas Sema men wear rectangular carnelian beads.

The use of a gauntlet or wristband is common among many Naga groups. Among the Sema it is known as a samogha and is made of seven to eight rows of cowries, the dorsal sides of which have been filed flat on a stone. The cowries are sewn as close as possible on to a cloth, with cane strips at both ends, and fastened on to the wrist by a string. The wristband is generally fringed with red dyed hair (Fig. 7). In the days of headhunting, cowrie 


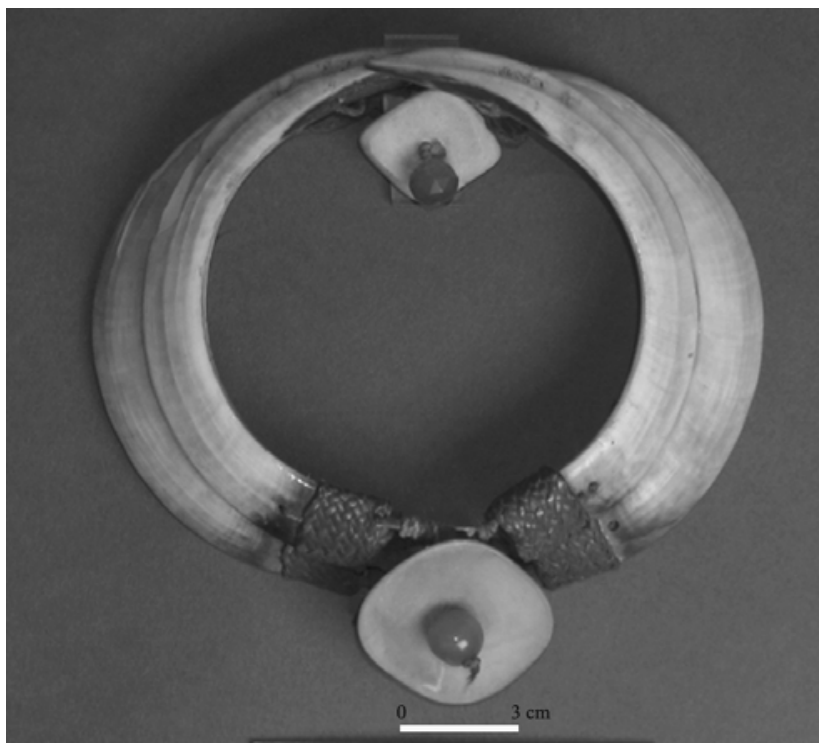

Fig. 6. An aminihu, a Sema necklace made of pig tusks with carnelian button fasteners.

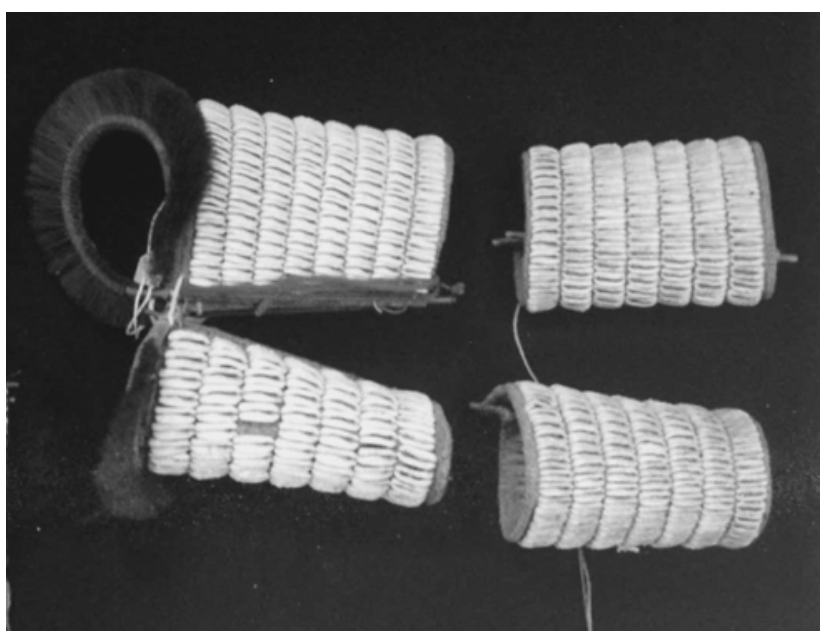

Fig. 7. Samogha, Sema cowrie-decorated gauntlets.

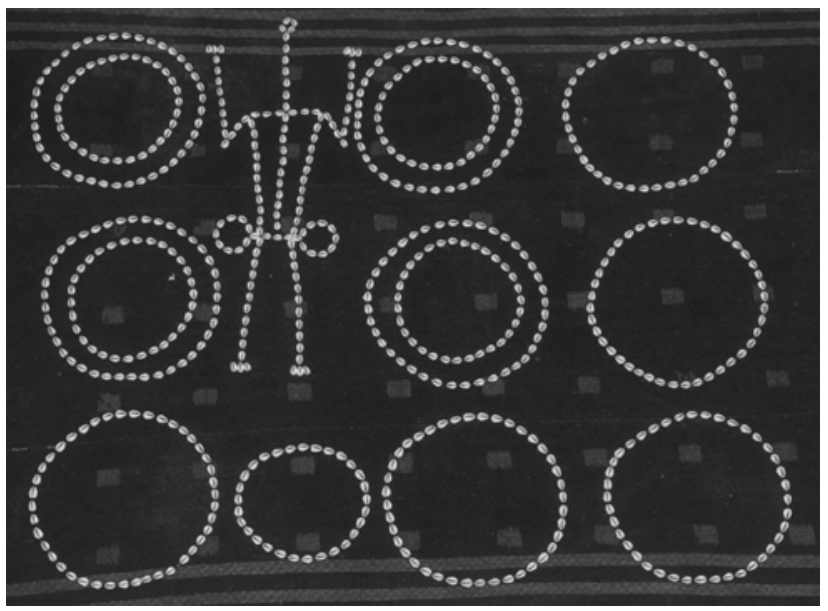

Fig. 8. Circles and a human figure design on a Sema kilt. gauntlets were restricted to only those who had drawn the blood of enemies, and were, therefore, status symbols. This type of gauntlet is also worn by the Aos.

The Sema kilt is ornamented with circles of cowries, sometimes with cowrie patterns designed as human figures (Fig. 8). Over the top of this a big square cloth covered with cowries (amini-kedah), is worn. This is about $45 \mathrm{~cm}$ long by $30 \mathrm{~cm}$ broad. The top $8 \mathrm{~cm}$ or so is taken up with cowries arranged on the black coloured cloth in more or less geometrical figures, while the rest is covered with cowries laid as closely as they can be, with a very narrow line being left vacant in the middle to facilitate folding (Fig. 9). Some other Naga communities, like the Rengmas, Lothas and Hatigoria, also supplement their waist cloths in this way.

The dress of the Sema women consists principally of a short petticoat, which does not reach to the knees, wrapped round the waist. The wives of chiefs and others who have performed a full series of social gennas (rites) sometimes adorn their petticoats with cowries sewn here and there in patterns. Over the petticoat, they wear a broad girdle of yellow Indo-Pacific glass beads extending well below the hips, so broad as to suggest that this was originally the piece-de-resistance of the costume (Fig. 10). This is worn by Ao and Konyak women too.

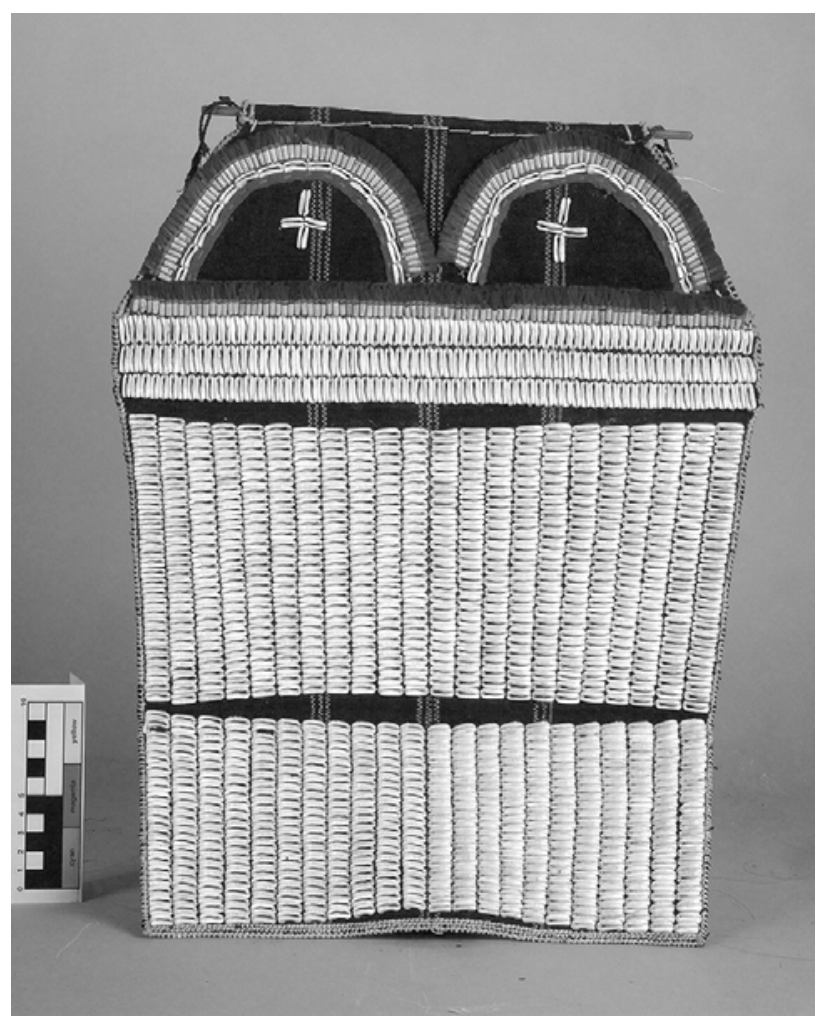

Fig. 9. An amini-kedah, an apron sewn with cowries.

The Ao

The full dress of an Ao warrior consists of boar tusks and strings of carnelian and conch shells on the neck, ivory bangles on the wrist, a red-coloured badge made of goat's hair on the chest, sewn with cowries and overhanging in front, and a spear with a decorated handle (Mills 1926). 


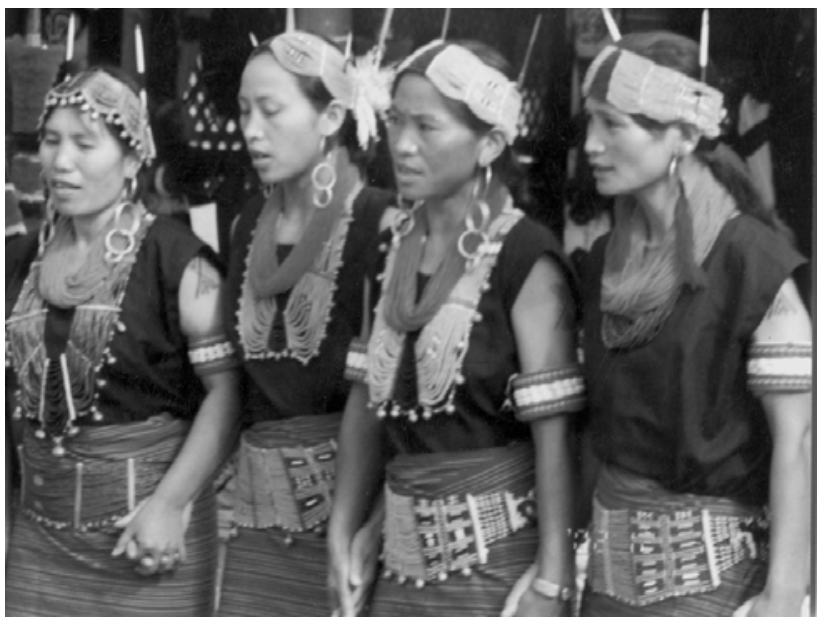

Figure 10. Sema women wearing bead girdles.

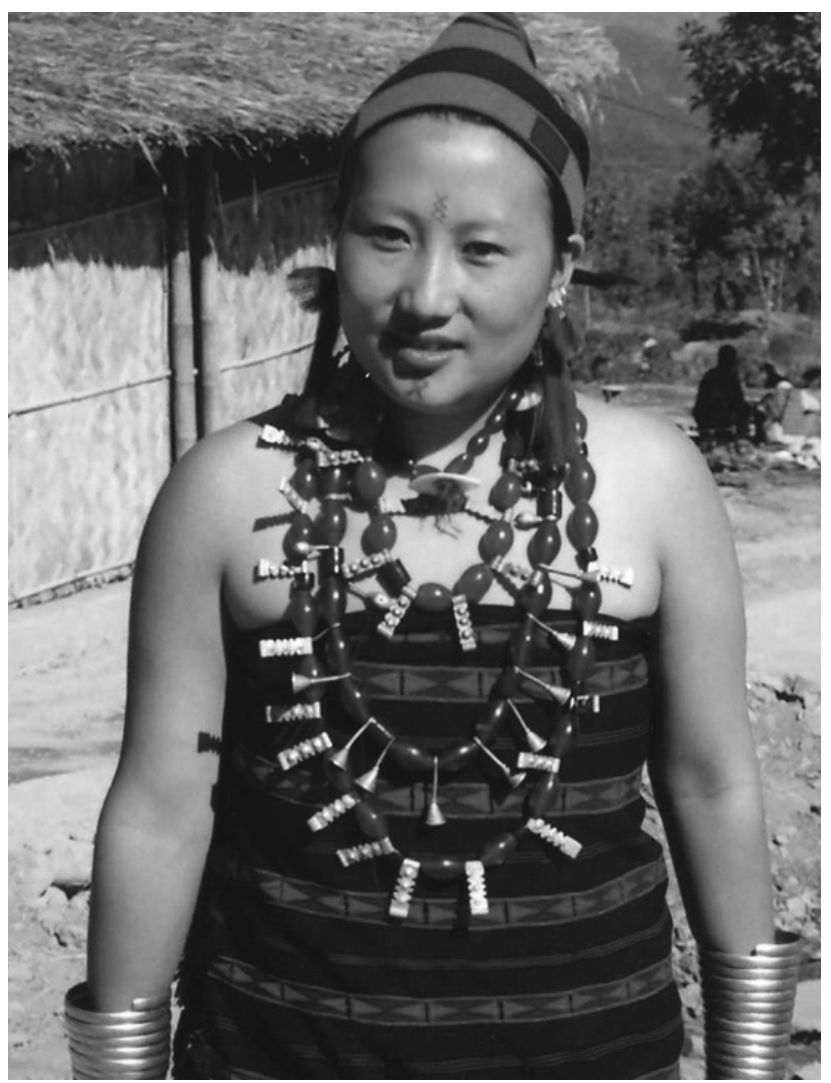

Figure 11. An Ao woman wearing mesemyok necklaces.

Over their richly embroidered skirts and shawls, Ao women wear four heavy necklaces known as mesemyok. These consist of carnelian beads, spikes of conch-shells, and brass bells of different sizes. The typical and most precious Ao women's necklace contains large carnelian beads alternating with miniature trumpet-shaped metal ornaments (Fig. 11). A pair of transparent crystal ear ornaments known as tongbang, about $5 \mathrm{~cm}$ across and 1.5 $\mathrm{cm}$ thick, square or circular in shape, are also status symbols among them (Fig. 12). The most antique ones are of polished rock crystal and are called mailbong naru. Once worn, these are ordinarily not taken off. In order to wear

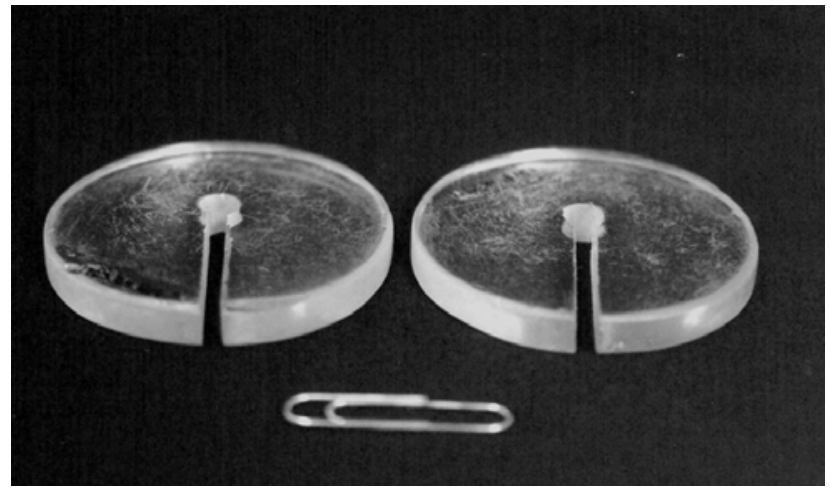

Fig. 12. A pair of tongbang crystal earrings.

them, the holes in the earlobe must be large enough. For this, the hole is bored in infancy and gradually enlarged with cotton wool and a wooden plug until it is big enough to take the tongbang, which is worn with the opening pointing downwards. Possession of these earrings is judged potentially dangerous and they are, therefore, subjected to rules which neutralize negative charges. For example, a new owner of a pair of khanas (the Tangkhul term for tongbang) sacrifices a chicken on his way home so that his wife or daughter will have a long life and, thereby, enjoy the acquisition of these earrings. Ganguli (1984:132) and Kaping (1998: 107) report the continuing use of khanas by the Tangkhul Nagas of the Somra tract on the India-Myanmar border. In the olden days, these earrings were often valued as much as a mithan (Bos frontalis), an animal sacred to the Nagas. The earrings used to come from far off places, and hence had great value.

\section{The Konyak}

The Konyaks constitute a major section of the Nagas and are prolific users of ornaments of conch shells, cowries, and Indo-Pacific glass beads. The villages of Chui, Cingphoi, Kongnue, Langkhai, Teae, Wakshing, Wanching, and Yosah in Nagaland are predominantly inhabited by them.

Konyak women use glass beads in massive quantities, along with other ornaments. Around their necks they wear several chains of black beads made of wild banana seeds, and green, red and yellow Indo-Pacific glass beads. Around their hips they wear wide belts made of similar beads. On their wrists they wear a number of metal bangles or conch shells, and heavy brass armlets just above their elbows. Sometimes they wear whole conches with their columellas cut away to make bangles, as photographed by Hutton (1930:81) in Nokphang village (Fig. 13). In their ears, Konyak women wear a bunch of orange feathers of small birds, tied together with an orchid stalk attached to a thin bamboo stick.

During traditional headhunting days Konyak body ornamentation was very rich and strictly guarded with many social customs. Head-takers were considered as warheroes and allowed to decorate themselves with all kinds of ornaments, like boar's tusk necklets, conch disc ear ornaments, and various other beads. Today, the use of 


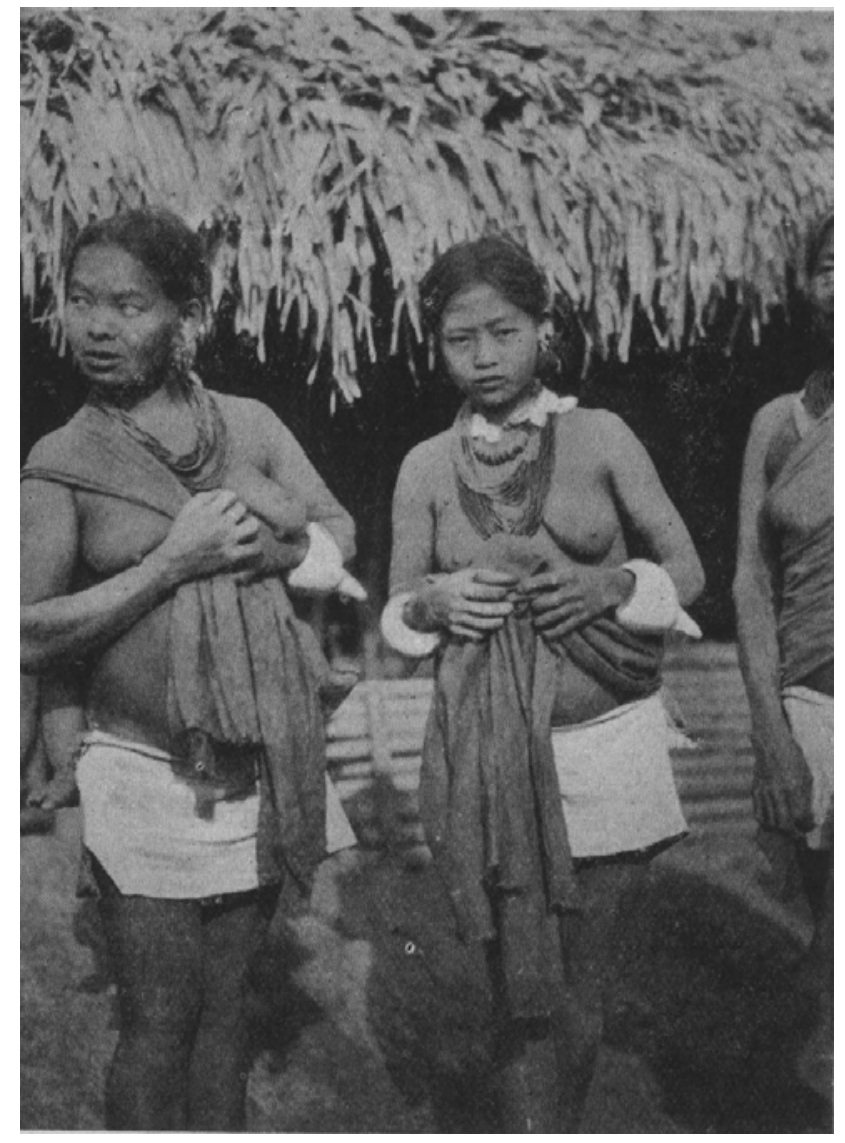

Fig. 13. Konyak women wearing complete conch shell bracelets (Hutton 1930, reprinted with permission from Blackwell).

some of these ornaments continues. As early as the 1930s, alternatives to headhunting for acquiring the rights to wear certain ornaments had come into existence. Haimendorf (1933) recorded that in headhunting dances even boys as young as six years could acquire the right to wear the head-hunting costume. Even now, social taboos associated with these ornaments are so strong that when I visited Chui village in 1999, the Konyak villagers needed the permission of the village elders or council members to show me their traditional ornaments.

The description given by Butler (1875:327) of Naga women's clothing (Fig. 14), which was more or less the same as that of the Konyaks (Fig. 15) and the present day Bondos (Fig. 16) of Orissa, is most interesting:

The most important perhaps, though least seen, portion of a woman's dress is of course the petticoat, which is usually a piece of dark blue home-spun cotton cloth, about 2 feet $[60 \mathrm{~cm}]$ in breadth, which passing round the hips overlaps about 6 inches $[15 \mathrm{~cm}]$. This is partially, if not entirely, covered by the folds of the next most important article of clothing, a broad cotton cloth, whose opposite corners are taken up and made to cross over the back and chest, thus covering the bosoms, and are tied in a knot over the shoulders. Finally, a second cloth is worn, either thrown loosely over the shoulders, or wrapped round the hips and tucked in at the waist. In the cold weather, they gener- ally add an extra cloth, whilst in the warm weather, or when employed in any kind of hard work, such as tilling their fields, \&c., they generally dispense with both these, and drop the corners of the other, or in other words simply strip to the waist.

Round their throats they love to load themselves with a mass of necklaces of all kinds, glass, carnelian, shell, seeds, and stone. In their ears the young girls wear a peculiar pendant formed of a circular bit of white shell, whilst the matrons generally dispense with earrings altogether. On their wrists above their elbows they wear thick heavy bracelets, or armlets, of brass, and a metal that looks like pewter.
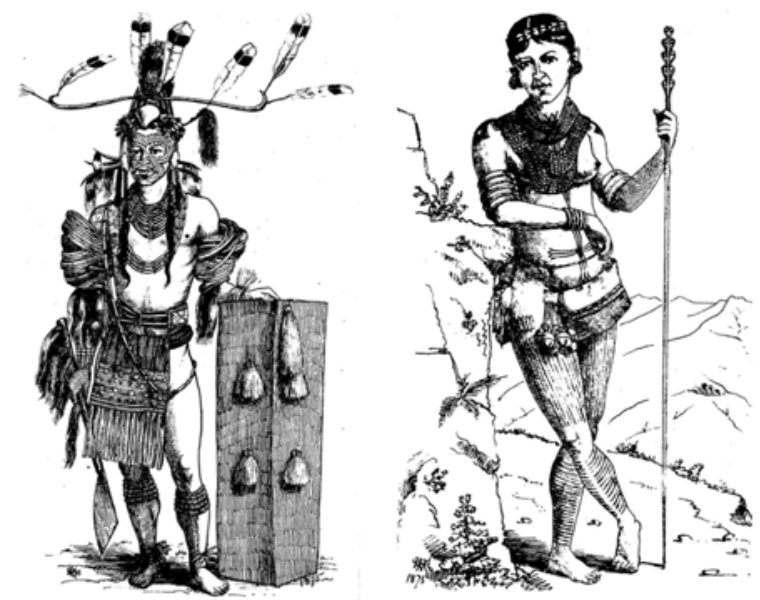

Fig. 14. A Naga man and woman, from Butler 1875.

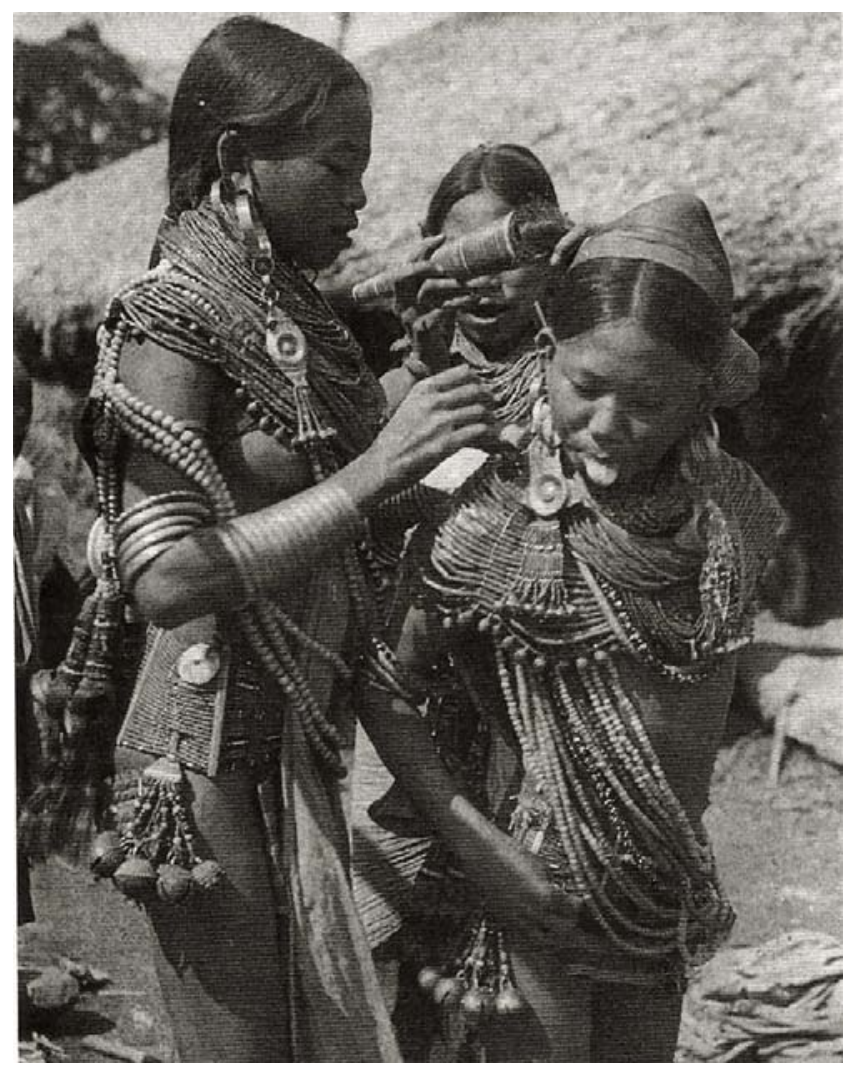

Fig. 15. Konyak women (Furer-Haimendorf 1933). 


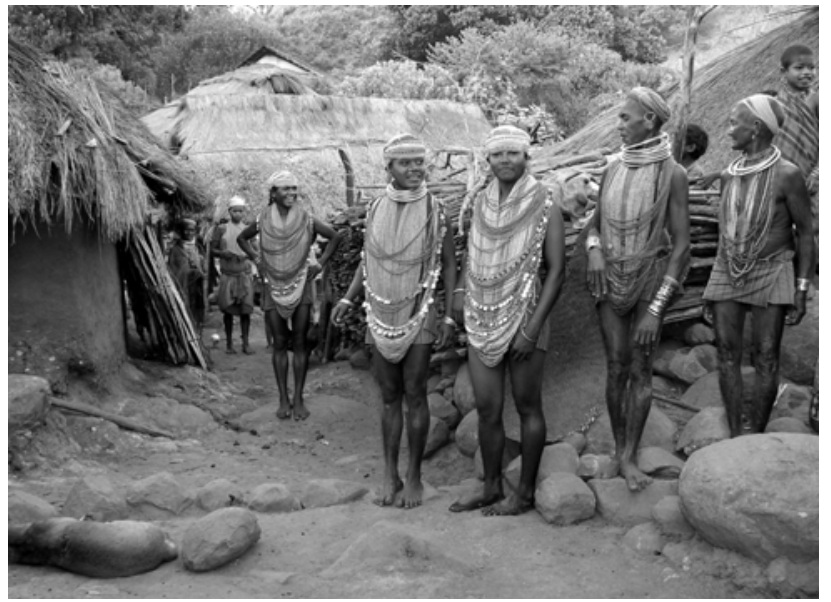

Fig. 16. Present day Bondo women, Orissa.

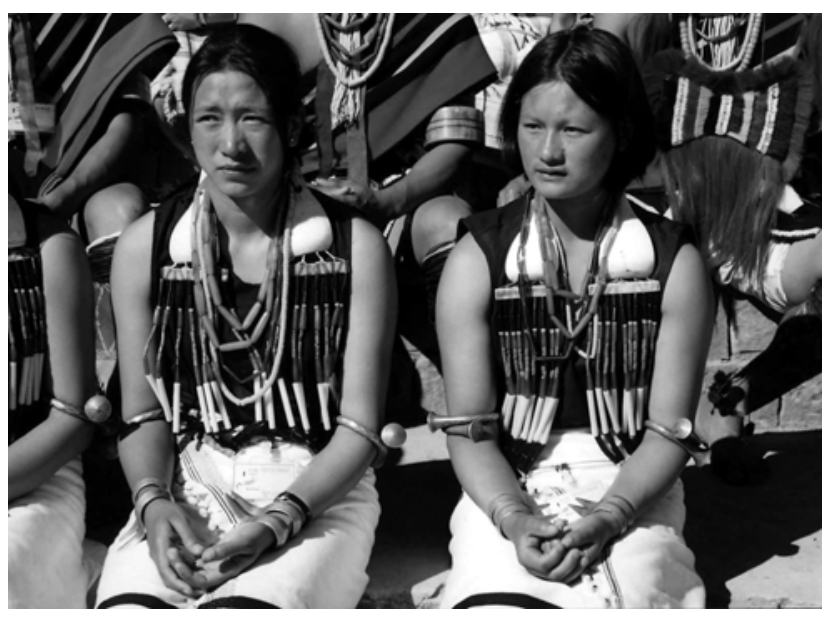

Fig. 17. Two Angami girls with tsubo necklaces of long hexagonal carnelian beads.

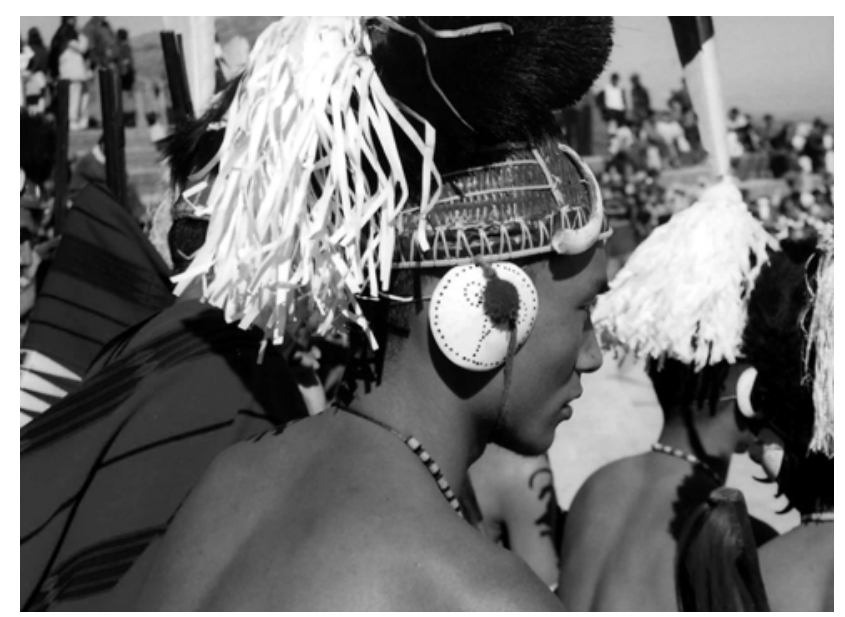

Fig. 18. Shell ear-discs of Angami type.

\section{The Angami}

The Angamis are one of the most referred-to communities in the Indian subcontinent. Referring to Angami male ornaments during the $19^{\text {th }}$ century, Butler (1875:320) and
Woodthorpe (1882a) mentioned the use of strings of glass beads around the neck along with beads of long hexagonal blood-red carnelian and shell. Very often, beads made of Solanum khasianum fruit have been wrongly identified as yellow stone beads.

A tsubo is the most prized of necklaces among the Angamis. Because of its spectacular aspect, other Naga groups, such as the Chakhesangs, Aos, Semas and Rengmas have adopted it, with modifications. The materials for making this type of necklace consist of beads of carnelian, glass of various colour, pearls, and ivory or bone spacers engraved with geometrical patterns (Fig. 17). Both men and women wear them.

Hutton (1921:23) referred to the use of black beads made by the Kacha Nagas from plantain seeds, as among the Konyaks, and triangular pieces of conch shell worn both as pendants and as beads, with carnelian buttons. The eastern Angami women wear the same necklaces as their men-folk. The kilt of the Angamis is same as that of the Semas. In the time of Butler (1875) and Woodthorpe (1882a), an Angami person wearing a kilt with three rows of cowries was identified as a warrior, and with four rows as a veteran. Angami women never wore them. As noted, Sema women wear cowries strung horizontally as a belt, while Rengma and some Dayang valley Sema women, whose husbands have performed certain feasting ceremonies, are allowed to wear clothes embroidered with cowries (Hutton 1921:27).

\section{NAGA TRADE}

Ganguli (1984:7) reports from the Ahom chronicle that lively trade and commerce flourished between the Bori Nagas and the Assamese. The Nagas bartered salt, cotton, medical herbs, ivory, bees' wax, mats and daos (machetes) for rice, cloth and beads from Assam. Majumdar (1924:42) listed Naga exports and imports in the 1920s. The indigenous products of the Naga hills brought down for sale in the plains were cotton, rubber, tea, sugarcane and cardamom, while the chief imports were beads, bangles of glass, zinc or brass, boar tusks, ivory and glass. These were chiefly imported from Kolkata, Mumbai and Myanmar. He further noted that the Angamis were engaged in widespread commercial activity, and used a public path to Myanmar through Manipur. For this travel the Sema hills route was generally adopted.

Hutton (1921) and Henry Balfore (personal diaries in Pitt Rivers Museum, Oxford) referred to the manufacture of shell beads and ear discs by the Angamis of Khonoma village, where they are still produced today. The Chang, Phom, Konyak and Yimtsung Nagas wear such ear discs (Fig. 18). Only the plain discs are traded, being finished by the end-users. Thus, they differ in design from community to community.

Since the time of Hutton (1926: 223), conch shells, from which these ornaments are made, have been imported from Kolkata or Dacca by Angami traders. However, Hutton believed that this trade was recent. The limited supply of shell ornaments in the Naga territories is apparent from their high value in the mid $19^{\text {th }}$ century, as 
recorded by Butler (1855: 157). A male slave was worth one cow and three conch shells, a female slave three cows and four or five conch shells. Hornell (1942:121) recorded that a male slave at that time was worth one cow and three conch shells, and a female slave much more valuable. A cow was valued at ten conch shells, a pig and a goat at two each; a fowl was worth only one packet of salt. However, about eighty years later (Hutton 1926:223), the supply of shells had become more frequent, and thus a reasonably good shell could be bought for five rupees.

Hutton (1929:47) further recorded that untreated cowries were brought from Myanmar to the villages of Angfang in the Tuensang region and Khonoma in the Angami region, and there cut and ground to the required shapes (generally rectangular), so as to lie flat on the cloth. Nowadays, these villages acquire their shells mostly from Kolkata, and sometimes from middlemen in Assam. A number of cowrie hoards have been reported from historical levels in archaeological sites in Assam. Chaudhury (1991) reports three such hoards in earthen pots containing thousands of cowries, from Guwahati, Lanka, and Hajai in Nagon district. Though Chaudhury hypothesises their use as currency items, the possibility that they were intended for trade to Naga territories cannot be ruled out.

\section{SOCIAL STATUS AND ORNAMENTS}

In Naga society, ornaments whose use is not subject to social control are rare. The majority mark a holder's membership in a certain clan, age group, or rank. They can demonstrate also that a person has performed certain rituals or ceremonies. Furthermore, ornaments not only express status, but also power. Every male Naga, if he is to acquire merit and status in this world and wear ornaments, must give a series of feasts, every detail of which is strictly prescribed (Mills 1935:134). At specific stages in this series he and his wife gain the right to wear special clothes, which increase in splendour and in the elaborateness of their embroidery the further he advances.

Less than half a century ago it was the ambition of every Naga to take a head, not only for personal glory and for the magical benefits to his village, but also because of the ornaments it entitled him to wear. Mills (1935:134-35) records that when Naga headhunting was discouraged by the British there was an invariable complaint that "our ornaments will die out". He mentions the changes needed to keep the ornamentation alive, but with social control, as for instance by killing a tiger instead of taking a head.

\section{ORNAMENTS AND DEATH}

Ornaments among Nagas are socially controlled not only in life, but also in death. In the event of unnatural death all possessions, including ornaments, are left either at the place of death or in the abandoned house occupied by the family of the deceased. This practice was present among most Nagas in the past but is now restricted to the interior. In Tuensang region, one finds even today many such abandoned collapsed houses.

A custom still followed by the Lothas is that in the event of an accursed/exceptional death, that is to say, a death in childbirth or by drowning or other accident, everything in the household of the dead person is abandoned. Not even the house is allowed to burn, until it collapses on its own. Nobody enters or touches the belongings, including money (Mills 1935: 135, 1938). Losing a head on a raid was considered disgraceful, and no honour was accorded to slain heroes - their families suffered disgrace and they had to abandon their property and possessions (Haimendorf 1933). Hatigoria men who died violent deaths, for instance by tiger attack or accident, were simply left where they fell, without covering or ornament, as their death was attributed to the disfavour of the Gods.

For normal burials, bodies were wrapped in mats and placed on a roofed platform inside a fence. Personal belongings such as clothes and shields were arranged around the platform (Woodthorpe 1882b). When a woman died, her friends and relatives hung a basket with offerings on a post by the head of the grave. On a bamboo stand by the side of the grave they hung the departed woman's clothing, ornaments and utensils which she had used during her life, and which she would use again in the land of the dead. After the period of mourning (six days for men and five for women), the clothing, ornaments and weapons were brought back from the grave and symbolically replaced by cheaper ones. At the time of the annual harvest ceremony (tuku-emung) ceremony all offerings would be removed from the graves, thus ensuring a process of recycling amongst relatives.

\section{DISCUSSION}

The adornment and decoration of the human body features in all known cultures and societies. Each culture develops its own costumes and ornaments, producing appearances which not only serve to enhance individual attractiveness, but also indicate the social roots of the person. Traditional costume marked out a person as belonging to a discrete cultural unit, and often indicated his or her standing within that community. It is rare to find a community, especially among the Nagas, which does not have its own characteristic and distinctive costume. It is vital in signifying that a person has complied with certain rituals, warfare, and feasts of merit. Ornaments reveal the wearer's economic and social status in the society.

The question arises of why the Nagas were so attached to their ornaments that they were prepared to pay heavy prices for them, involving mithans and slaves, and also prepared to engage in head-hunting to gain the status to wear them. For centuries, probably millennia, the Nagas remained relatively untouched by the higher civilizations of India and Myanmar. On the Indian side, the only place accessible to them was Assam. Yet, on their discovery, they used large quantities of shell, stone and glass ornaments which originated from as far as $2500 \mathrm{~km}$ away. Cambay (Gujarat) was the production centre for carnelian beads since Harappan times. Indo-Pacific beads were produced in large quantities on the southeast coast from the third century BC to perhaps the $17^{\text {th }}$ century AD (Francis 2002). There is also ethnographic evidence for the survival of this industry at Papanaidupet near Tirupati in 
Andhra Pradesh (Kanungo 2000-2001). Furnace wound beads are today only produced at Purdalpur, a small town in Uttar Pradesh (Kanungo 2004a, 2004b, 2006). The conch shell species Turbinella pyrum occurs from Godavari to Rameswaram on the east coast of India, while in the west it is only found in the Gulf of Kutch.

There is still a very strong tradition in the Naga Hills of immigration from the southeast, although it is perhaps unlikely that they originally lived near the Indian ocean. Nevertheless, the question of the origins of the Nagas is an interesting one that requires more research.

\section{ACKNOWLEDGEMENTS}

The author is grateful to the Northwest Bead Society, USA, for financial support to carryout fieldwork in Nagaland; to the Nehru Trust for visiting the Indian Collections at the Victoria and Albert Museum, and the British Academy for financial support to visit various museums in the UK to examine Naga ornaments. The Indo-Pacific Prehistory Association provided the forum in Taipei to present the results of the research, and Prof. V. N. Misra read an earlier draft of the paper. David, Dam, Vilie, Toshi and Lezotto provided invaluable help during the fieldwork.

\section{REFERENCES}

Bagchi, P.C. 1944. India and China, a Thousand Years of SinoIndian Cultural Contact. Calcutta: China Press Limited.

Butler, J. 1855. Travels and Adventures in the Province of Assam: During a Residence of Fourteen Years. London: Smith Elder \& Co.

1875. Rough notes on the Angami Nagas and their languages. Journal of the Asiatic Society 44(1): 307-346.

Choudhury, R.D. 1991. On three hoards of cowries from Assam. In J.P. Singh and G. Sengupta (eds), Archaeology of North-Eastern India, pp. 228-31. New Delhi: Hal-Aand Publications in association with Vikas Publishing House.

Francis, P. 2002. Asia's Maritime Bead Trade 300 B.C. to the Present. Honolulu: University of Hawai'i Press.

Furer-Haimendorf, C. von. 1933. Naked Nagas. Calcutta: Thacker Spink.

Ganguli, M. 1984. A Pilgrimage to the Nagas. New Delhi: Oxford \& IBH

Hornell, J. 1942. The chank shell cult of India. Antiquity 16: 113-33.
Hutton, J.H. 1921. The Angami Nagas. London: Macmillan.

1926. Naga chank ornaments of south Indian affinity. Man 26: 222-24.

1929. Diaries of two tours in the unadministered area east of the Naga hills. Memoires of the Asiatic Society of Bengal 9(1): 1-72.

1930. Naga chank ornaments of south Indian affinity. Man 30: 81.

Kanungo, A.K. 2000-01. Glass beads in Indian archaeology - an ethnoarchaeological approach. Bulletin of the Deccan College Post-Gradate \& Research Institute 60-61: 33753.

2004a. Glass Beads in Ancient India: An Ethnoarchaeological Approach. Oxford: British Archaeological International Reports Publication series 1242.

2004b. Glass beads in ancient India and furnace-wound beads at Purdalpur: an ethnoarchaeological approach. Asian Perspectives 43(1): 123-150.

2006. Glass Bead Production Centers: an Ethnoarchaeological Assessment. In G. Sengupta, S. Roychoudhury \& S. Som (eds), Past and Present: Ethnoarchaeology in India, pp. 411-27. New Delhi: Pragati Publishers and Kolkata: CASTEI.

Kaping, T. 1998. The Southern Nagas: An Ethnoarchaeological Study. Ph.D. Dissertation. Pune: Deccan College PostGraduate and Research institute.

Majumdar, S.N. 1924. The Ao Nagas. Man in India 4(1-2): 2856.

Mills, J.P. 1926. The Ao Nagas. London: Macmillan.

1935. The effect of ritual upon industries and arts in the Naga hills. Man 35: 132-35.

1938. The Lhota Naga "Apotia” death. Journal of the Indian Anthropological Institute 1: 23-27.

Needham, J. 1954. Science and Civilization in China, Vol. I. Cambridge: University Press.

Woodthorpe, R.G. 1882a. Notes on the wild tribes inhabiting the so-called Naga hills, on our north-east frontier of India. Part I. Journal of the Anthropological Institute of Great Britain and Ireland 11: 56-73.

1882b. Notes on the wild tribes inhabiting the so-called Naga hills, on our north-east frontier of India. Part II. Journal of the Anthropological Institute of Great Britain and Ireland 11: 196-214. 